See discussions, stats, and author profiles for this publication at: https://www.researchgate.net/publication/267240951

\title{
Outward FDI and home-country performance: Evidence from Italian manufacturing and service firms
}

Article · May 2010

DOI: 10.3846/bm.2010.011

CITATIONS

3

3 authors:

Cesare Imbriani

Sapienza University of Rome

25 PUBLICATIONS 100 CITATIONS

SEE PROFILE

Filippo Reganati

Sapienza University of Rome

53 PUBLICATIONS 200 CITATIONS

SEE PROFILE

Some of the authors of this publication are also working on these related projects:

Project sistema finanziario e squilibri terriotriali View project

Project Multinationality and firm survival View project
Rosanna Pittiglio

University of Dundee

36 PUBLICATIONS 144 CITATIONS

SEE PROFILE 


\title{
OUTWARD FDI AND HOME-COUNTRY PERFORMANCE: EVIDENCE FROM ITALIAN MANUFACTURING AND SERVICE FIRMS
}

\author{
Cesare Imbriani ${ }^{1}$, Rosanna Pittiglio ${ }^{2}$, Filippo Reganati ${ }^{3}$ \\ ${ }^{I}$ Istituto Economia e Finanza, University of Rome, La Sapienza, Rome, Italy \\ E-mail: cesare.imbriani@uniroma1.it \\ ${ }^{2}$ Dsems, University of Foggia, Foggia, Italy \\ E-mail: r.pittiglio@unifg.it \\ ${ }^{3}$ Sociologia e Comunicazione, University of Rome, La Sapienza, Rome, Italy \\ E-mail: filippo.reganati@uniromal.it
}

\begin{abstract}
How does outward foreign direct investment (FDI) affect employment and productivity growth in the home country? Does the impact of outward investment differ among manufacturing and service sectors? In this paper, we analyze the effects of investing abroad using firm-level data for Italy in the period 2003-2006. We adopt matching techniques in combination with a difference-in-difference estimator in order to investigate the causal effect on domestic employment and productivity of becoming multinational. Preliminary results suggest that, on average, Italian outward FDI has limited effects on the domestic employment and performance of internationalizing firms. However, results differ significantly according to the sector (manufacturing versus services) in which the MNEs operate. In particular, we find that whereas in the manufacturing sector, outward FDI tends to strengthen both productivity and to a lesser extent employment, in the service sector there is a negative effect on both employment (two years after the investment) and productivity.
\end{abstract}

Keywords: outward FDI, employment effects of FDI, propensity score, MNEs.

\section{Introduction}

In evaluating the economic effects of the activity of multinational enterprises (MNEs), a great deal of attention is being given to the effects of outward Foreign Direct Investment (FDI) on home-country performance. In particular, one major concern is that by opening new foreign subsidiaries, MNEs may reduce employment in their home countries.

From a theoretical point of view, it is not clear whether engaging in foreign production will have a positive or negative effect on activities at home. According to Hanson et al. (2003), the effect on domestic activities depends on the degree of complementarity between foreign and domestic stages of production. If foreign production partially substitutes domestic stages of production, then engaging in FDI reduces the firm's domestic activity. However, many foreign activities aim to enlarge the market of domestic firms. In this case, foreign and domestic production are complements. Moreover, increasing activities abroad might affect the firm's productivity for at least three reasons. Firstly, the relocation of production stages might increase productivity through a better allocation of resources. Secondly, specialization might increase productivity through scale economies and/or learning. Thirdly, activities abroad might expose the firm to new technologies, ideas and knowledge that could also be used at home.
In the last two decades, the effects of outward FDI on home country performance have received a great deal of attention. Using different methodological approaches, empirical evidence generally shows that outward FDI tends to strengthen the economic activities of domestic firms both in terms of employment and productivity.

As far as Italy is concerned, recent contributions on becoming a multinational firm report a significant and positive impact on productivity and employment both in general (Barba Navaretti, Castellani 2004) and by controlling for the countries of destination of outward FDI (Barba Navaretti et al. 2006). However, despite the recent boost of FDI in the service sector, comparison between manufacturing and service internationalizing firms has scarcely been done. Between 2003 and 2007, the Italian MNEs operating in the service sector increased their share from 18 to $23 \%$ in terms of employees and from 62 to $68 \%$ in terms of number of firms.

The main aim of this paper is to study how the effect of moving abroad on domestic employment and productivity of internationalizing firms depends on conditions related to the parent's sector of activities (manufacturing versus services).

We use detailed firm-data to analyze whether the internationalization of Italian firms has changed the level of activities at home. We compare the activities of firm that have engaged in FDI 
(hence, MNEs) to the activities of domestic firms that do not have affiliates abroad (hence, national firms). Yet, the activities of national and multinational firms are not easily comparable since the group of multinational firms is not randomly drawn from the whole population of firms. According to Helpman et al. (2004), a firm selfselects into this group when it reaches a certain threshold level of productivity. National and multinational firms thus differ ex-ante. Differences in their performance cannot therefore be related only to their internationalization decision. We tackle this problem by applying a matching approach. We identify all national firms that have become multinational in our sample period and find their closest neighbour among the group of national firms that have not switched. Therefore, switchers and their closest neighbours do not differ ex-ante. The differences in their ex-post performance can be directly related to foreign activities. We combine this matching approach with a difference-indifference estimation methodology proposed by Heckman et al. (1997). This estimation methodology allows the change in performances of a switcher to be compared with the change in performances of a national firm during the sample period.

The rest of the paper is structured as follows. The next section reviews the empirical literature, while section 3 presents the data. The econometric specification is described in the subsequent section, and the results are illustrated in section 5 . Section 6 concludes.

\section{How economists have evaluated the effects of OFDI on Employment: a brief survey of the literature}

In the last two decades, numerous studies have estimated the impact of OFDI on the home countries trying to evaluate whether and how the opening of a foreign affiliate might affect domestic employment. These studies are differentiated according to the variable measured (number of employees, composition and/or growth of employment), kind of FDI (Vertical or Horizontal), method of analysis (dynamic model, PSM, PSM with DID, conditional PSM with DID) ${ }^{1}$, sector of activity (manufacturing and services) and, naturally, the home country considered. Given the complexity of this literature, we have tried to divide these studies into four categories:

1) Analyses of the OFDI effects on the labour intensity of the activities carried out in the Home

${ }^{1}$ PSM: Propensity Score Matching; DID=Difference in differences
Country (Blömstrom et al. 1997; Fors, Kokko 1999; Mariotti et al. 2003).

Using firm level data on a sample of US and Swedish firms, Blömstrom et al. (1997) found that larger production in developing countries by a U.S. firm was associated with lower labour intensity at home. Moreover, Swedish firms tended to use more labour per unit of output at home if they produced more abroad, probably because production abroad required supervisory and other auxiliary employment at home. The authors justified this difference by highlighting how the Swedish investments in developing countries were concentrated in import substitution activities, and the affiliates exported little of their output, much less than U.S. affiliates.

The analysis of Swedish firms was further examined by Fors, Kokko (1999) who, by focusing on a sample of seventeen of the largest MNCs, tried to provide a rough picture of how internationalization was connected with structural changes in the home-country operations of the MNCs. The authors found that the changes taking place within the MNCs were greater than had been recognized in the literature. Looking at the population of plants owned by the MNCs and summarizing the results of their analysis, they found annual turnover rates of about 10\% for the period 1986-1994. Moreover, in most of the industries in which the seventeen MNCs present in the sample had operations both in Sweden and abroad, they found that the domestic and foreign employment moved in opposite directions.

Finally, Mariotti et al. (2003) provided further insights into the relationship between homecountry employment and FDI undertaken by a sample of Italian firms over the period 1985-1995. In the study, in order to capture both the direct and indirect effects of foreign production on the parent's environment, the authors considered as the unit of analysis each ensemble of firms operating in the same industrial sector and localised in the same geographical region. The results of the work suggested that the impact of outward FDI on the labour intensity of domestic production is negative when vertical investment is undertaken in less developed countries, and positive for horizontal and market-seeking investments in advanced countries. The negative impact is mainly due to the transfer of labour intensive and low-skilled intensive activities abroad. By contrast, the positive impact for horizontal FDI is closely connected to the need for more supervision, coordination and control over geographically spread activities.

2) Studies analysing how OFDI do influence the division of labour within MNEs - e .g. deter- 
mining a higher concentration of skilled labour intensive activities at home (Kravis, Lipsey 1993; Slaughter 2000; Head, Ries 2002; Falzoni, Grasseni 2005; Hansson 2004; Mariotti, Piscitello 2006).

In this regard, when analysing manufacturing and service sectors in US firms, Kravis, Lipsey (1993) found that a firm that produces largely abroad tends to allocate the more labour intensive and less skill-intensive portions of its activity to locations outside the US. This relationship is more marked among manufacturing firms than service industry firms, probably because services are less tradable than manufactured goods. Moreover, according to these authors, service industries may therefore be less able to break up the production process to take advantage of differences in factor price. Head, Ries (2002), when looking at a sample of Japanese MNEs over the period 1956-1990, identified a positive and significant effect on the parent company's skill intensity which was higher when foreign affiliates were located in lowincome countries. Likewise, Hansson (2004) found that the relocation of activities by Swedish MNEs to non-OECD regions in 1990-1997, in particular to Central Eastern European countries, contributed to the skill upgrading of their home activities.

Nevertheless, the evidence significantly differed when the unit level of analysis was changed. For example, Head and Ries in the same work published in 2002, carried out an investigation at industry level and, similarly to the results obtained by Slaughter (2000) on US MNE, did not find a significant effect of foreign production on the qualitative composition of the domestic labour force. By contrast, as far as the Italian case is concerned, Falzoni, Grasseni (2005) showed that the expansion of international production by Italian MNEs produced a positive impact on the average relative wages at home that, however, did not depend on the location of foreign affiliates.

3) Studies empirically investigating the substitution possibilities between parent company employment and foreign affiliate employment (Brainard, Riker 1997; Hanson et al. 2003; Becker et al. 2005; Cuyvers et al. 2005; Konings, Murphy 2006; Murphy 2006; Harrison et al. 2007; Desai et al. 2009).

This set of works estimates the elasticity of substitution between parent company employment and foreign affiliate employment, using data both on relative employment and relative wages. In these analyses, a positive impact of a foreign affiliate's wage on home-country employment indicates a substitution effect (e.g. production is relocated from the affiliate to the parent if ceteris paribus the wage level of the affiliate increases). On the other hand, a negative coefficient of crosswage elasticity indicates that employment in the affiliate and the parent is complementary (e.g. the international vertical decomposition of the value chain). However, the findings obtained from these studies depend on the characteristics of the host countries of affiliates analysed and the sector of activity (manufacturing or non-manufacturing).

So, for example, for the US manufacturing firms and relating to the period 1983-1992, Brainard, Riker (1997) found a weak, but significant labour substitution effect between parent companies and their affiliates. Moreover, they showed that the substitutability in employment was much stronger among different affiliates of the same MNE that were located in different low- cost host countries. In a later paper, always for the US Multinational but relating to a different period (two sub-periods: 1989-1994 and 1994-1999), Hanson et al. (2003) measured a significant positive association between higher sales in foreign affiliates and US parent employment.

Konings, Murphy (2006) and Murphy (2006), using firm level data of European MNEs for the period 1993-1998, found no evidence for substitution effects between parent employment and affiliates located in the CEEC. A significant and negative correlation between parent employment and affiliate employment was identified for affiliates based in North EU and EU15 only in the manufacturing sector. These substitution effects are nonexistent for MNEs in the non-manufacturing sector. A significant and positive relation between employment growth in the foreign affiliates and employment in the parent companies was identified by Desai et al. (2009) when looking at data on US manufacturing firms spanning the period 1982-1999.

4) Studies analysing the causal cffect of establishing a foreign affiliate on domestic employment by using PSM. A different approach was followed by the fourth group of studies (Barba Navaretti, Castellani 2004; Debeare et al. 2006; Barba Navaretti et al. 2006; Hijzen et al. 2007), which investigated the causal effect of establishing a foreign affiliate on domestic employment by using matching techniques in combination with a DID estimator. The use of this approach permits a comparison between the performance of firms investing abroad for the first time with an appropriate counterfactual of national firms. Compared to previous studies, these analyses also allow us to understand what would have happened to the firms in the absence of investments. 
Using data on Italian manufacturing companies over a five-year period, Barba Navaretti, Castellani (2004) showed that becoming a multinational does not produce a significant effect on employment performance, but it was associated with a better performance in terms of total factor productivity and output growth. A limit of this work was, however, not to having considered the countries destination of investment, which may significantly influence its effect on employment. Some years later, Debaere et al. (2006) used the PSM approach on a sample of Korean manufacturing firms, finding that the effects of foreign investment on employment are closely linked to their destination: with FDI in less developed host countries reducing the employment growth in the parent companies. They found no-long run and permanent effects on employment growth rate. On the other hand, moving to more advanced countries, does not affect employment growth in any significant way.

In the same period and using a sample of French and Italian manufacturing firms over the period 1993-2001, Barba Navaretti et al. (2006) deepen the analysis presented in 2004 by classifying investments according to their destination. The reason for this was to capture the specific effect of investing in cheap labour countries. This allowed the authors to consider three different possibilities of multiple treatments in the propensity score: investing in a developing country, investing in a developed country or staying at home. From this analysis, the authors found no-evidence of a negative effect of outward investments to cheap labour countries. In particular, in Italy OFDI produce a positive long-term effect on value added and employment whereas for France, authors found a positive effect on the size of domestic output and employment.

Finally, Hijzen et al. (2007) applying the same technique for a large panel of Japanese manufacturing firms over the period 1995-2002, found that foreign investments produced a positive impact on the performance of domestic firms in terms of both productivity and employment.

\section{Data Description and Preliminary Data Analysis}

The empirical analysis has been conducted by using firm level data drawn from the AIDA database (Analisi Informatizzata Delle Aziende) provided by Bureau Van Dijk.

The AIDA database collects annual accounts of Italian corporate enterprises and contains information on a wide set of economic and financial variables i.e. number of employees, capital, value added, profits, intermediates goods, $R \& D$, cost of employees, start-up year as well as sector of activity and ownership status.

Our analysis covers the period 2002-2007 and regards firms operating in both manufacturing and service sectors. The information on the ownership status contained in the database, allows us to distinguish between domestically owned firms (National Firms) - that have not invested abroad during the period observed-and those that switch from being national to being MNEs (Switching firms)- firms that have opened their first foreign subsidiary in the period observed.

In identifying MNEs, we consider a participation rate benchmark of $10 \%$, so we consider parent an Italian firm holding a direct ownership share of at least $10 \%$ in one or more firms located in a country other than Italy.

By including all firms that have a complete list of variables and omitting all observations for which the necessary data are incomplete, we obtained a sample of 1,658 switching firms between 2003 and 2006.

Table 1 presents some descriptive statistics on characteristics of our sample by year, sector, size and investing status.

Table 1. Number and distribution of firms in the sample by year, sector, size class and investing status

\begin{tabular}{|c|c|c|c|c|c|c|}
\hline & \multicolumn{3}{|c|}{ Manufacturing } & \multicolumn{3}{|c|}{ Services } \\
\hline & $\begin{array}{c}\text { National } \\
\text { firms }\end{array}$ & $\begin{array}{c}\text { Switching } \\
\text { firms }\end{array}$ & Total & $\begin{array}{c}\text { National } \\
\text { firms }\end{array}$ & $\begin{array}{c}\text { Switching } \\
\text { firms }\end{array}$ & Total \\
\hline \multicolumn{7}{|l|}{ Year } \\
\hline 2003 & 20,131 & 32 & 20,163 & 18,425 & 12 & 18,437 \\
\hline 2004 & 18,609 & 72 & 18,681 & 18,407 & 42 & 18,449 \\
\hline 2005 & 18,181 & 531 & 18,712 & 12,724 & 263 & 12,987 \\
\hline 2006 & 17,878 & 509 & 18,387 & 18,241 & 197 & 18,438 \\
\hline \multirow[t]{3}{*}{ Total ( $N^{\circ}$ of firms) } & 74,799 & 1,144 & 75,943 & 67,797 & 514 & 68,311 \\
\hline & \multicolumn{6}{|c|}{ Size classes (\% of to tal firms) } \\
\hline & $\begin{array}{l}\text { National } \\
\text { firms }\end{array}$ & $\begin{array}{c}\text { Switching } \\
\text { firms }\end{array}$ & Total & $\begin{array}{l}\text { National } \\
\text { firms }\end{array}$ & $\begin{array}{l}\text { Switching } \\
\text { firms }\end{array}$ & Total \\
\hline 20-50 employees & 65.45 & 16.43 & 64.72 & 67.17 & 28.4 & 66.9 \\
\hline 50-100 employees & 20.89 & 28.67 & 21.01 & 18.4 & 25.68 & 18.45 \\
\hline 100-250 employees & 10.67 & 36.98 & 11.06 & 9.71 & 23.35 & 9.81 \\
\hline $\begin{array}{l}\text { more than } 250 \\
\text { employees }\end{array}$ & 2.99 & 17.92 & 3.21 & 4.72 & 22.57 & 4. 84 \\
\hline Total & 100 & 100 & 100 & 100 & 100 & 100 \\
\hline
\end{tabular}

As far as size is concerned, the sample reflects the large weight of small and medium-sized enterprises in the Italian economy-approximately $65 \%$ of cases have fewer than fifty employees. Moreover, remarkable differences emerge between switching and national firms, with the former being significantly more frequent in larger-sized classes. This suggests that switching firms may be very different from the average firm that has not invested abroad, so that a simple comparison between these two groups of firms might lead to bi- 
ased conclusions, as the latter may not provide an accurate approximation to the counterfactual.

\section{Econometric Methodology}

\subsection{Matching Procedure}

In order to evaluate the impact of investing abroad on the economic performance of Italian firms, we use a propensity score matching technique (Rosenbaum, Rubin 1983, Caliendo, Kopeinig 2005). This allows us to construct the counterfactual through the selection of a valid control group of national firms that do not invest abroad but are as similar as possible in their observable characteristics to firms that invest. ${ }^{2}$

The core idea of PSM is that the bias due to differences in the characteristics of OFDI and Non-OFDI group are reduced if the comparison of outcomes - in our case, change in employment - is made both by using firms that have invested abroad, and a control group of national firms which are as similar as possible to later MNEs in their observed characteristics before the first group's firms became multinational. The PSM method offers a way of summarising the number of characteristics of firms into a single variable indicating the probability of doing outward FDI, the propensity score.

The propensity score is estimated by using a probit model where the dependent variable is a dummy variable (at time $t$ ) indicating new outward investors $\left(\mathrm{Swi}_{\mathrm{i}, \mathrm{t}}\right)$ that is equal to 1 if the firm changes status and zero otherwise.

$$
P\left(S w i_{i, t}=1\right)=F\left(X_{i, t-1}\right)
$$

The explanatory variables that may affect the choice of investing abroad are common determinants of FDI. In particular, we include TFP, employment (as a proxy for firm size), the R\&D intensity (the ratio between $R \& D$ expenditure and sales), the capital-labour ratio, firm age, the profit ratio (the ratio between operating profit and sales) and average wage (the ratio between cost of employees and number of employees). ${ }^{3}$ We further

\footnotetext{
2 The regression approach based on OLS or other simple techniques may lead to misleading conclusions, since there may be the well-known endogeneity problem i.e. the correlation of explanatory variable with the error term (Smarzynska 2004, Smarzynska\&Arnold 2005). One possible remedy such as the use of the instrumental variable approach is difficult because good instruments for FDI decision are hard to find.

${ }^{3}$ TFP is a measure of total factor productivity calculated as the residual from a Cobb-Douglas production function, which is estimated separately for each Ateco 3-digit industry. In order to deal with the potential simultaneity problem in estimating firm level production functions, we employ the me-
}

include a full set of industry and year dummies. Following the suggestions in Sianesi (2002) and Caliendo, Kopening (2005), the exogenous variables are lagged by one year, $\mathrm{X}_{\mathrm{i}, \mathrm{t}-1}$ (at time $\mathrm{t}-1$ ).

Looking at the first column of Table 2, we can see that, for the manufacturing sector, all coefficients of explanatory variables have the expected signs and are statistically significant. For the service sector, all coefficients of the explanatory variables have the expected signs and are statistically significant except for the TFP that does not appear to exert a significant effect on the propensity to become a multinational (column 2).

Table 2. Probit Estimations

\begin{tabular}{|l|c|c|}
\hline & Man ufacturing & Services \\
\hline & $(1)$ & $(2)$ \\
Log N. em ployeesi,t-1 & $0.4196^{* * *}$ & $0.3211^{* * *}$ \\
Log R\&Di,t-1 & $(0.0201)$ & $(0.0599)$ \\
& $0.1853^{* * *}$ & \\
Log Profitsi,t-1 & $(0.0675)$ & \\
& $0.1037^{* * *}$ & $0.0501^{* * *}$ \\
Log Capital Labor ratioi,t-1 & $(0.0180)$ & $(0.0067)$ \\
& $0.0541^{* * *}$ & $0.0505^{* * *}$ \\
Log Agei,t-1 & $(0.0019)$ & $(0.0094)$ \\
& $0.0753^{* * *}$ & $0.0808^{* * *}$ \\
Log Wagei,t-1 & $(0.0146)$ & $(0.0132)$ \\
& $0.0541^{* * *}$ & $0.0569 * * *$ \\
Log TFPi,t-1 & $(0.0200)$ & $(0.0049)$ \\
& $0.0844^{* * *}$ & 0.0074 \\
Industrial dummy & $(0.0164)$ & $(0.0458)$ \\
Yeardummy & & \\
N. observations & Yes & Yes \\
Pseudo R-squared & Yes & Yes \\
$* * *, * * *$ : signific ant at $1 \%, 5 \%$ and $10 \%$ levels, respectively &
\end{tabular}

These results are in line with the theoretical underpinning (Helpman et al. 2004) which suggests that more productive and larger firms selfselect into multinationals.

From the estimation results, we obtain the probability of switching (propensity score) both for firms switching from 'national' to 'multinational' status, and for the firms that stay 'national'.

The propensity score effectively defines the neighbourhood for each treated observation and allows us to build the counterfactual. The literature proposes various matching methods. Since we can draw from a large control group, we use the three nearest neighbor matching method, i.e. each treated firm is matched according to its propensity score to its 3 nearest neighbors within its subsample.

In order to compare the propensity scores of firms with similar characteristics and to avoid, i.e. the matching of a firm in the textile sector in 2003 with a firm in electronic machineries in the same

thod proposed by Levinsohn\&Petrin (2003) using intermediate inputs as instrument. 
year, we have divided our firms into sub-sectors at one digit classification, i.e. 3 for the manufacturing and 7 for the service and, then, run the nearestneighbor algorithm year by year. Moreover, given the purpose to verify whether matching on the propensity score effectively balances the matched sample across individual observable characteristics, we perform standard t-tests for equality of means in the treated and non-treated for each variable in the propensity score before and after matching. Table 3 reports the means of a range of covariates in the unmatched and matched sample. As one would expect, the means of the treated and the control observations in the unmatched sample are typically statistically different. After matching, the t-tests for the equality of the means indicate that the balancing condition is satisfied in our matched sample.

Table 3. Balancing Tests

\begin{tabular}{|c|c|c|c|c|c|c|c|c|}
\hline & \multicolumn{8}{|c|}{ Unmatched Sample } \\
\hline & \multicolumn{4}{|c|}{ ManufacturingSector } & \multicolumn{4}{|c|}{ Services } \\
\hline & Treated & Control & $\begin{array}{c}\text { Percent } \\
\text { bias }\end{array}$ & $\begin{array}{c}\text { Test for } \\
\text { the } \\
\text { equality }\end{array}$ & Treated & Control & $\begin{array}{c}\text { Percent } \\
\text { bias }\end{array}$ & $\begin{array}{c}\text { Test for the } \\
\text { equality of } \\
\text { Means } \\
\end{array}$ \\
\hline Log N. employees $\mathrm{i}_{\mathrm{t}, \mathrm{l}}$ & 4.64 & 2.60 & 188.80 & 77.06 & 3.72 & 2.09 & 121.20 & 57.38 \\
\hline $\log R \& D_{i, t-1}$ & 0.01 & 0.00 & 5.20 & 6.27 & & & & \\
\hline Log Profits & 0.04 & 0.02 & 3.70 & 1.90 & 0.30 & 0.12 & 12.60 & 6.05 \\
\hline Log Capital Laborratio $_{i}$ & 10.32 & 9.56 & 46.00 & 15.59 & 9.89 & 8.84 & 38.10 & 12.61 \\
\hline $\log A g \mathrm{G}_{, \mathrm{t} 1}$ & 2.99 & 2.45 & 64.80 & 23.84 & 2.77 & 2.19 & 67.70 & 21.88 \\
\hline $\log \operatorname{TFP}_{\mathrm{i}, \mathrm{1} 1}$ & 15.37 & 12.71 & 157.60 & 58.04 & 13.91 & 11.68 & 119.90 & 55.58 \\
\hline \multirow[t]{2}{*}{$\log \mathrm{Wag}_{,+1}$} & 10.48 & 9.70 & 51.70 & 15.61 & 9.89 & 8.42 & 47.40 & 14.02 \\
\hline & \multicolumn{8}{|c|}{ Matched Sample } \\
\hline Log N. employees ${ }_{i t-1}$ & 4.64 & 4.70 & -5.10 & -1.30 & 3.71 & 3.76 & -3.40 & -0.66 \\
\hline $\log R \& D_{i, t-1}$ & 0.01 & 0.00 & 4.40 & 1.25 & & & & \\
\hline Log Profits:tit-1 & 0.04 & 0.04 & 0.10 & 0.03 & 0.30 & 0.20 & 6.60 & 1.43 \\
\hline Log Capital Labor ratio $_{i}$ & 10.32 & 10.33 & -0.40 & -0.15 & 9.89 & 9.89 & -0.10 & -0.02 \\
\hline $\log A g e_{1,1}$ & 2.99 & 3.01 & -3.00 & -0.93 & 2.77 & 2.78 & -1.40 & -0.36 \\
\hline $\log \operatorname{TFP}_{i, 1}$ & 15.37 & 15.31 & 3.90 & 1.11 & 13.90 & 13.98 & -4.20 & -0.84 \\
\hline Log Wage & 10.48 & 10.46 & 1.00 & 0.61 & 9.89 & 9.82 & 1.90 & 0.60 \\
\hline
\end{tabular}

\subsection{Estimation Strategy}

Following the microeconomic evaluation literature (Heckman et al. 1997; Blundell et al. 2004) we combine propensity score matching with the DID analysis. In particular, the effect on economic performance at home of becoming a multinational firm is evaluated by comparing the average in the performance of the switchers and the non-switchers. In fact, we apply two different approaches.

First, we simply compare the average in performance between the treated and control groups after the event of switching. In this case, the estimator (ATT) is given by (2)

$\alpha_{A T T}=\overline{y_{t}^{1}-\overline{y_{t}^{0}}}$

where $\overline{y_{t}^{1}}$ is the mean performance of investing firms after the switching and $y_{t}^{0}$ is the mean performance of the control group over the same period of time. The average treatment effect on the treated (ATT) can be thought of as a test for the equality of means in performance growth over the switching and the matched groups.

Even though we have controlled for the nonrandom switching decision, unobserved heterogeneity could still bias our results. Such unobserved heterogeneity might result from firm specific characteristics (organizational structures, special market condition or management skills) and for the time-invariant elements (common macro effects).

So, we use a difference-in-difference estimator (DID) which compares the average differences in pre- and post-event performances of both groups. Formally, the DID estimator is given by (3):

$\alpha_{D I D}=\left[\begin{array}{cc}{ }^{1} & { }^{1} \\ \bar{y}_{t-}-\bar{y}_{t+}\end{array}\right]-\left[\begin{array}{cc}0 & 0 \\ \bar{y}_{t-} & -\bar{y}_{t+}\end{array}\right]$

Where the over bars indicate averages in each group performance before and after switching.

The outcome variables in our analysis are the employment level and the TFP. In both cases, we calculate the yearly growth rates. As shown in Meyer (1995), both the ATT and DID estimators may be obtained from OLS estimation. In particular, DID can be estimated from the following regression:

$\Delta y_{i t}^{s}=\beta_{0}+\beta_{1} d_{t}+\beta_{2} d^{s}+\alpha_{D I D} d_{t}^{s}+x_{i t}^{s^{\prime}}+\varepsilon_{i t}^{s}$

Where the covariates $x$ control for other sources of heterogeneity and $d$ refers to different sets of dummies. The superscripts $s=n, c$ refer to the status of the firms, with $n$ denoting those firms that do not change status and $c$ the ones that do; the subscripts $t=0,1$ refer to the period before and after the change of status.

To summarise, the dummies take on the following values:

$$
\begin{aligned}
& d_{t}=1 \text { if } t=1 \text { and zero otherwise, } \\
& d^{s}=1 \text { if } s=c \text { and zero otherwise, } \\
& d_{t}^{s}=1 \text { if } t=1 \text { and } s=c \text { and zero otherwise. }
\end{aligned}
$$

The coefficient of interest is the third one, $\alpha_{D I D}$. If it is positive (negative), it implies that changing status has a positive (negative) effect on the employment (productivity) growth rate. The first and second dummy variables will respectively control for any difference between the pre- and post-change period and between firms that change status and the ones that do not. Setting $t=1$ in regression (4), we obtain the standard matching estimator $(S M \alpha)$.

$\Delta y_{i t}^{s}=\beta_{0}+\beta_{1} d_{t}+\alpha_{A T T} d^{s}+x_{i t}^{s^{\prime}}+\varepsilon_{i t}^{s}$ 
In other words, in this case we focus on the differences in the performance growth in the period after the investment decision.

\section{Estimation Results}

Using the matched sample, we use DID estimator in order to evaluate the causal impact of switching towards multinational production overseas on home performance. Table 4 and Table 5 report the average differences in TFP and employment between the switching firms and the matched domestic firms one, two and three years after the establishment of the affiliate abroad.

Table 4. Growth of domestic performance -ATT estimator

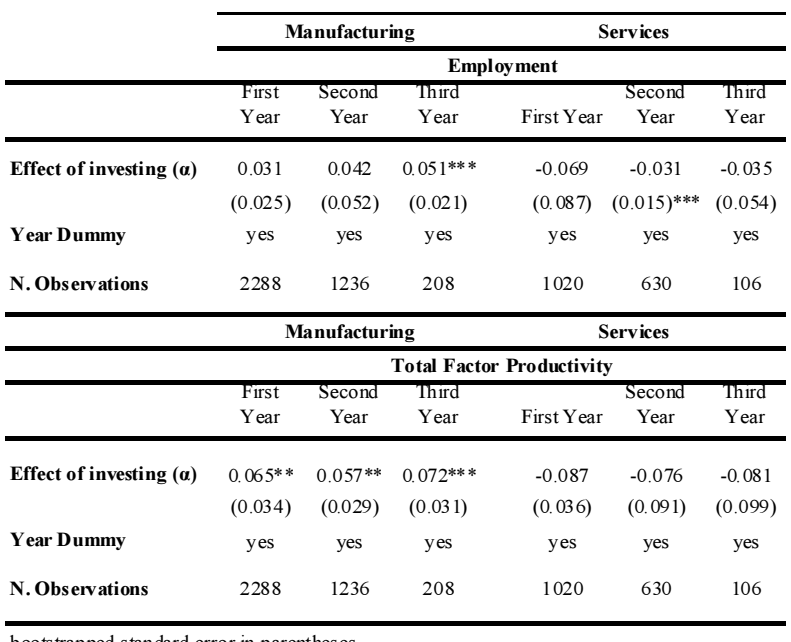

The estimates show that the average causal effect on employment of locating production abroad is positive, but not significant, in the first and in the second year after investment. It becomes significant only in the third year. This result is slightly different to that of Barba Navaretti, Castellani (2004), which found a positive and significant effect on the first year after the investment.

We also find a positive and significant impact of production abroad on TFP growth: switching firms have a $6.5 \%$ higher growth rate in productivity than their domestic counterfactual in the year following the investment. The positive effect is also present both in the second and in the third year after the investment. This outcome would be in line with the expectation that the relocation of domestic production to a foreign country determines productivity gains as the less productive assembling activities are sent abroad.

By accounting for the pre-switching performance dynamics (DID estimator), we found that the establishment of a manufacturing affiliate has the same (insignificantly) positive effect on firm's performance at home in the first two years after the investment. In the third year, the positive and significant effect is lower than the one found using ATT estimator. We also observe that switching firms increase their firm level TFP, relative to the counterfactual in the switch and in the following years.

As far as the service sector is concerned, the results from our empirical analysis suggest that becoming multinational has a negative impact on domestic employment, particularly two years after becoming a multinational.

Table 5. Growth of domestic performance - DID estimator

\begin{tabular}{|c|c|c|c|c|c|c|}
\hline & \multirow{2}{*}{\multicolumn{3}{|c|}{ Manufacturing }} & \multirow{2}{*}{\multicolumn{3}{|c|}{ Services }} \\
\hline & & & & & & \\
\hline & \multicolumn{6}{|c|}{ Employment } \\
\hline & $\begin{array}{l}\text { First } \\
\text { Year }\end{array}$ & $\begin{array}{c}\text { Second } \\
\text { Year }\end{array}$ & $\begin{array}{l}\text { Third } \\
\text { Year }\end{array}$ & $\begin{array}{l}\text { First } \\
\text { Year }\end{array}$ & $\begin{array}{c}\text { Second } \\
\text { Year }\end{array}$ & $\begin{array}{l}\text { Third } \\
\text { Year }\end{array}$ \\
\hline \multirow[t]{2}{*}{ Effect of investing ( $\alpha$ ) } & 0.029 & 0.032 & $0.021 * * *$ & -0.057 & -0.029 & -0.031 \\
\hline & $(0.025)$ & $(0.065)$ & $(0.009)$ & $(0.031)$ & $(0.056)$ & $(0.076)$ \\
\hline Year Dummy & Yes & yes & yes & yes & yes & yes \\
\hline \multirow[t]{4}{*}{ N. Observations } & 4576 & 2472 & 416 & 2040 & 1260 & 212 \\
\hline & \multicolumn{3}{|c|}{ Manufacturing } & \multicolumn{3}{|c|}{ Services } \\
\hline & \multicolumn{6}{|c|}{ Total Factor Productivity } \\
\hline & $\begin{array}{l}\text { First } \\
\text { Year }\end{array}$ & $\begin{array}{l}\text { Second } \\
\text { Year }\end{array}$ & $\begin{array}{l}\text { Third } \\
\text { Year }\end{array}$ & $\begin{array}{l}\text { First } \\
\text { Year }\end{array}$ & $\begin{array}{c}\text { Second } \\
\text { Year }\end{array}$ & $\begin{array}{l}\text { Third } \\
\text { Year }\end{array}$ \\
\hline \multirow[t]{2}{*}{ Effect of investing ( $\alpha$ ) } & $0.070^{* * *}$ & $0.074^{* * *}$ & $0.081 * * *$ & $-0.061 * * *$ & -0.056 & -0.081 \\
\hline & $(0.034)$ & $(0.020)$ & $(0.032)$ & $(0.029)$ & $(0.078)$ & $(0.076)$ \\
\hline Year Dummy & Yes & yes & yes & yes & yes & yes \\
\hline N. Observations & 4576 & 2472 & 416 & 2040 & 1260 & 212 \\
\hline
\end{tabular}

bootstrapped standard error in parentheses

The effect on TFP is negative during the entire period under observation, and significant only in the first year after the investment.

Finally, when we accounted for the preswitching performance dynamics (DID estimator) we found that the effect of internationalization is negative but not significant for the employment growth, whereas it is negative and significant for the TFP growth in the first year.

\section{Conclusions}

In the present paper, we investigate the causal effect on home performance of becoming a multinational with regard to a large panel of Italian firms. In particular, we adopt matching techniques in combination with a DID estimator to evaluate the causal effect on productivity and employment of establishing a foreign affiliate. Preliminary results suggest that, on average, Italian outward FDI has limited effects on the domestic employment and performance of internationalizing firms. However, results differ significantly depending on the sector of activity of MNEs (manufacturing versus services). In particular, we find that whereas in the 
manufacturing sector, outward FDI tends to strengthen both productivity and to a lesser extent employment, in the service sector there is a negative effect on both employment (two years after the investment) and productivity.

\section{References}

Barba Navaretti, G.; Castellani, D. 2004. Does Investing Abroad Affect Performance at Home? Comparing Italian Multinational and National Enterprises. CEPR Working Paper.

Barba Navaretti, G.; Castellani, D.; Disdier, A. C. 2006. How Does Investing in Cheap Labour Countries Affect Performance at Home? France and Italy. Development Studies WP 215-Centro Studi Luca D'Agliano.

Becker, S. O.; K. Ekholm; Jäckle, R.; Muendler, M. A. 2005. Location Choice and Employment Decisions: A Comparison of German and Swedish Multinationals, Review of World Economics 141(4): 693731. doi:10.1007/s10290-005-0052-6

Blundell, R.; Costa Dias, M.; Meghir, C.; Van Reenen, J. 2004. Evaluating the Employment Impact of a Mandatory Job Search Assistance Program, Journal of European Economic Association.

Brainard, S. L.; Riker, D. 1997. Are U. S. Multinationals Exporting U.S. Jobs? NBER Working Paper, no. 5958.

Caliendo, M.; Kopeinig, S. 2005. Some Practical Guidance for the Implementation of Propensity Score Matching, IZA Discussion Paper 1588.

Cuyvers, L.; Dumont, M.; Rayp, G.; Stevens, K. 2005. Home Employment Effects of EU Firms' Activities in Central and Eastern European Countries, Open Economies Review 2: 153-174. doi:10.1007/s11079005-5873-3

Debaere, P.; Lee, H.; Lee, J. 2006. Does Where You Go Matter? The Impact of Outward Foreign Direct Investment on Multinationals' Employment at Home. CEPR Discussion Paper 5737.

Desai, M. A., Foley, C. F.; Hines, J. R. 2009. Domestic Effects of the Foreign Activities of US Multinationals, American Economic Journal: Economic Policy 1(1): 181-203. doi:10.1257/pol.1.1.181

Falzoni, A. M.; Grasseni, M., 2005. Home Country Effects of Investing Abroad: Evidence from Quantile Regressions. CESPRI.

Fors, G.; Kokko, A. 1999. Home Country Effects of FDI: Foreign Production and Structural Change in Home Country Operations, in The Seventh Sorbonne International Conference, Paris, June 1999.

Hanson, G. H.; Mataloni, Jr.; Slaughter, M. J. 2003. Expansion Abroad and the Domestic Operations of
U.S. Multinational Firms, Manuscript. Tuck School of Business at Dartmouth, Hanover, NH.

Hansson, P. 2004. Skill Upgrading and Production Transfer within Swedish Multinationals in the 1990s. CEPS Working Documents, 163.

Harrison, A. E.; Mcmillan, M. S. ; Null, C. 2007. US Multinational Activity Abroad and US Jobs: Substitutes or Complements? Industrial Relations: A Journal of Economy and Society.

Head, K.; Ries, J. 2002.Offshore Production and Skill Upgrading by Japanese Manufacturing Firms, Journal of International Economics 58(1). doi:10.1016/S0022-1996(01)00161-1

Heckman, J.; Ichimura, H.; Todd, P. 1997. Matching as an Econometric Evaluation Estimator: Evidence from Evaluating a Job Training Program, Review of Economic Studies, 64.

Helpman, E.; Melitz, M. J.; Yeaple, S. R. 2004. Export Versus FDI with Heterogeneous Firms, American Economic Review 94(1): 300-316. doi: $10.1257 / 000282804322970814$

Hijzen, A.; Inui, T.; Todo, Y. 2007. The Effects of Multinational Production on Domestic Performance: Evidence from Japanese Firms. RIETI Discussion Paper.

Konings, J.; Murphy, A. 2006. Do Multinational Enterprises Relocate Employment to Low Wage Regions? Evidence from European Multinationals, Review of World Economics 142(2). doi:10.1007/s10290-006-0067-7

Kravis, I. B.; Lipsey, R. E. 1993. The Effect of Multinational Firms' Operations on Their Domestic Employment. NBER Working Papers 2760.

Murphy, A. P. 2006. An Assessment of the Implications of EU Enlargement for Foreign Direct Investment and Jobs in Ireland. The Central Bank\&Financial Services Authority of Ireland.

Rosenbaum, P.; Rubin, D. 1983. The Central Role of the Propensity Score in observational Studies for Causal Effects, Biometrika 70: 41-50. doi:10.1093/biomet/70.1.41

Sianesi, B. 2002. An Evaluation of the Swedish System of Active Labour market Programmes in the 1990, IFS Working Papers W02/01. Institute for Fiscal Studies.

Slaughter, M. 2000. Production Transfer within Multinational Enterprises and American Wages, Journal of International Economics 50(2). doi:10.1016/S0022-1996(98)00081-6

Smarzynska, J. B. 2004. Does Foreign Direct Investment Increase the Productivity of Domestic Firms? In Search of Spillovers through Backward Linkages, The American Economic Review 94(3): 605-27. doi:10.1257/0002828041464605 